\title{
Treatment of polluted municipal wastewater in Tashkent
}

\author{
Malokhat Abduqodirova", and Bohodirkhodja Ismoilkhodjayev \\ Tashkent Institute of Irrigation and Agricultural Mechanization Engineers, Tashkent, Uzbekistan
}

\begin{abstract}
This article presents the results of a comparative study of the method of biological treatment using aquatic plants and algae to improve the technology of treatment of domestic and municipal wastewater treatment plants formed in urban areas. According to test results, 5 species of aquatic plants and 2 strains of algae tested, pistachio and eucalyptus species, and strains of Chlorella vulgaris UA-1-6 were found to be resistant to domestic wastewater. This water plant laripistiya and eichorniya species grow well in different wastewater concentrations $(25 \%, 50 \%, 100 \%)$ in the $100 \%$. Both water treatment stations have a high yield and treatment levels. It was observed that it reached $90 \%$ at the "Binokor" water treatment station and the water treatment station "Salar" - 82-86\%. This is because the amount of harmful substances in the wastewater of the "Salar" water treatment station is 5 times higher than the number of pollutants in the water treatment station "Binokor". It should be noted that the results of wastewater treatment works at 2 water treatment plants showed that the type of pistachio plant is more resistant to wastewater than the type of eucalyptus, and the level of treatment is also high. Therefore, in the experiment at the "Salar" water treatment station, we found it necessary to use the pistachio water plant itself. At this wastewater treatment station, wastewater treatment reached an average of $84 \%$, and to increase the treatment efficiency, we grew Chlorella vulgaris in the second treatment stage and found that the treatment efficiency was $90-92 \%$. This means that the treatment of wastewater in each treatment station requires the development of biological treatment technology following it.
\end{abstract}

\section{Introduction}

It is known that the Earth consumes $3300-3500 \mathrm{~km} 3$ of water per year, and the water demand is growing every year. This is due to the expansion of cities, the rapid development of industry and agriculture, the expansion of irrigated lands, population growth and the improvement of their living conditions, and other factors that complicate the water supply problem to mankind. As a result, a quarter of the world's population now lives in countries with drinking water shortages.

In addition, the population is expected to reach 7.8 billion by 2030 , and as a result, the demand for water resources will require another $50 \%$ of the water used by 2025 . This is already the case in several African countries, the Middle East, and even developed

\footnotetext{
*Corresponding author: abduqodirova78@mail.ru
} 
European countries. The above-mentioned negative developments have not bypassed the Republic of Uzbekistan, and this problem is getting worse every year. One of the factors in its prevention and elimination is the rational use of water resources, reuse of used water, and improvement of water protection measures [1-3].

One of the main tasks of perfect use and protection of water resources is the treatment of industrial enterprises, agricultural production, and utilities for various purposes, especially the biological treatment of urban wastewater [4-6].

The most important sources of water pollution are industrial and municipal wastewater. These effluents store various substances that are dangerous to live organisms, which contaminate the effluents with lakes and reservoirs [6-8].

Some of the used water is currently treated, and the rest $(50 \%)$ is discharged into the reservoirs without being completely treated. One of the main ways to prevent such negative consequences, i.e., to keep the hygienic condition of water bodies clean, is to build various wastewater treatment plants, apply modern methods, develop a scientific basis for the reuse of treated wastewater $[5,9,10]$.

Currently, Research is being conducted in many countries around the world on wastewater treatment. In this Research, Research is being conducted in various areas, and developments are being developed to protect water resources from various harmful substances and develop measures for the treatment of polluted water.

Of particular interest is the study of the mechanism of purification of hazardous contaminants by microscopic algae. V. Matamoras et al. (2016) found that the number of heavy metals in wastewater decreased significantly $(65-70 \%)$ after the cultivation of Chlorella sp algae. Another researcher proved that the strain of Chlorella vulgaris ifr s-111 absorbs up to $86 \%$ of the ammonium cation and up to $70 \%$ of the phosphorus anion in the municipal wastewater. (Temnov et al., 2017) K. Diskinson et al. (2015) Scenedesmus sp worked on the assimilation of biogenic elements in urban wastewater through a continuous algae cultivation regime and the production of biofuels from this algae biomass. In addition, researchers are conducting extensive Research in the field of wastewater treatment from industrial enterprises. For example, A.Khabibrakhmanova et al. (2016) determine that up to $67-70 \%$ of copper ions in the wastewater formed in the ore processing plant, copper electrolyte plants, and galvanic shops can be absorbed by algae. N.Bolshakov (2013) studied the possibility of reducing the amount of phosphorus in the reservoirs of fishery category to the norm of REK by deep biological treatment with the help of algae.

Some researchers (Ostalkovich et al. 2016) have shown that using bacteria, it is possible to purify metals from liquid radioactive waste due to enzymatic-denitrification, metalloreductase, and biosorption processes in the cell.

One of the most important works is the use of oxygen, filtrotenka, biodisk and biological basins in aerobic biological treatment, and the use of two-stage anaerobic-ferob oxidation treatment in high-concentration industrial effluents. Phase I is the methane tank, stage II are aerotanks, and before these processes, it is necessary to remove waste oil and resin by treatment. These proposed biological technologies are complex, costly, and not economically and technologically suitable for all facilities. Therefore, experts have pointed out the need for the design of the treatment plant, taking into account the economic factor and the population in municipal wastewater treatment. They proposed 3 types of projects depending on the population. Type 1 are settlements with a population of up to 20 thousand. Category 2 are settlements with a population of 50-100 thousand, Category 3 are large cities and megacities, and Category 1 facilities are mainly biological elements $(\mathrm{N}, \mathrm{P}$, S) - deep biological aerobic treatment is sufficient. As Category II and III facilities contain metals and biogenic elements (as a result of the addition of industrial effluents), it is necessary to have filtration facilities and sorption filters before biological treatment. (Pupyrev et al. 2014: Kazmiruk KV, Kazmiruk T-2015) 
Based on the above information and depending on the existing economic conditions and characteristics of the facilities in the country, we aim to conduct Research on the development of low-cost and technologically simple biological treatment technology. There are 4 wastewater collection facilities in Tashkent, and we compared the Salar aeration station, which collects $70 \%$ of the city's wastewater, and the Binokor treatment plant, which accounts for $7 \%$.

According to E. Pulyrev's classification, the Salar aeration station belongs to the I category. The Binokor sewage treatment plant belongs to the II category. In the development of biological wastewater treatment technology, we mainly pay attention to the characteristics of the biological objects used. To select aquatic plants that can absorb metals such as copper, iron, chromium, and other elements in addition to biogenic elements in the water, and for deep biological treatment of these elements, two-stage technology, stage 1 aquatic plants, and stage 2 algae technology we offer. These proposed treatment processes are simpler, less costly, and more efficient and mainly carried out in aerotanks and biological pools. Type II treatment plant "Binokor" wastewater treatment is sufficient to grow a single-stage aquatic plant, as the amount of elements in the wastewater is five times less than in the type I treatment plant.

It is shown that this technology can be used in villages, cottages, rest homes, as well as in livestock complexes and poultry (V.Kazmiruk, T.Kazmiruk 2015)

Based on the above data, biological treatment of domestic wastewater is poorly understood, and insufficient Research has been done to reduce the treatment time and increase the level of treatment, especially with the combined use of algae and aquatic plants. With this in mind, we plan to conduct Research on the biological treatment of wastewater at aeration stations for the formation of domestic, municipal wastewater in Tashkent.

A comparative study of the biological treatment methods of domestic, municipal wastewater at 2 aeration stations in Tashkent with the help of algae and aquatic plants is to improve the technology for each object.

The main tasks for the study were: - From each algae and aquatic plant, each aeration station selects the appropriate species resistant to wastewater, to determine the degree of cultivation of the selected algae and aquatic plants in different concentrations in wastewater under laboratory conditions.

\section{Materials and Methods}

The Research was conducted at Salar in Tashkent and Binokor aeration station in Orta Chirchik district of the Tashkent region. Sewage samples were taken from the entrance to each aeration station treatment plant. To select the type of wastewater resistant as a biological treatment plant, we selected the following species from the collection of aquatic plants (pistachio, eucalyptus, azole, ryaska, wolfia) from the algae chlorella vulgaris UA-16 and stsepedesmus obligus UA-2-7 (plants UzFA Botany Institute was taken from the collection). We grew these plants for 5 days in $100 \%$ wastewater brought from aeration stations. During this time, we determined the daily growth, morphological condition, and yield of the plants. The yield was determined by weighing wet biomass. The physical and chemical properties of wastewater before and after the experiment were carried out according to the Yu.Yu.Lure method. The color of the effluent was determined by measuring the optical density of the water at a spectrophotometry instrument, at different wavelengths, after the algae had grown and grown. (Lure, 1984). To do this, 2 hours after sampling, the filtrate is discarded, and the next $10 \mathrm{~cm}$ thick cuvette (the second cuvette is filled with distilled water) is measured on a SF-46 instrument with a wavelength of 400760 , and the color of the water is determined. Water odor detection is mainly done in the 
room - smoking, cologne, use of perfumes, no colds, no allergies before detecting the odor. To determine the odor, it is necessary to determine the number of vapors, that is, to find the point at which the odor of the detected water does not come after how much the water is diluted with pure water. To do this, add 2.5.10.50.100.150 $\mathrm{ml}$ of deodorizing water to a 500 $\mathrm{ml}$ flask and make up to $200 \mathrm{ml}$ with fresh water. Another flask is filled with $200 \mathrm{ml}$ of clean water as a control option, and the flasks are closed with a lid. After some time, open the lids of the flasks and sniff one by one, and finally smell fresh water. Then determine the number of parog in the diluted flask and find the number of parog using the following formula:

$$
\text { Number of Parog }=\frac{A+B}{A}
$$

Here: A is the volume of water under analysis, $\mathrm{ml}$; B is the volume of fresh water diluted, $\mathrm{ml}$.

The number of hydrogen ions in wastewater is determined mainly by the electrometric method using glass electrodes. To determine the number of hydrogen ions, $\mathrm{pH}-\mathrm{meter}$ devices are used (LP-5, LPU-01, ionometer-I-105). Before measuring the number of hydrogen ions, buffer solutions with different $\mathrm{pH}$ are prepared, and to determine the $\mathrm{pH}$ in the measured (studied) water, its $\mathrm{pH}$ number is found based on the curvilinear calibration of standard buffer solutions.

In the gravimetric determination of sulfate ions, a sample of $25-500 \mathrm{ml}$ of wastewater is placed in a beaker, to which HCL is added (to a metallic flame color) and polished to 50 $\mathrm{ml}$. After polishing, a precipitate is formed. It is washed with hot distilled water and boiled until polished to another $50 \mathrm{ml}$. A drop of 5\% barium chloride solution is added to the complete precipitate of sulfate ions. The resulting precipitate solution is kept in a water bath for 2 hours and left in the cold until morning. The next day the precipitate is filtered, then washed in hot water, dried and weighed, and determined by the following formula:

$$
\begin{aligned}
& X=\frac{a \cdot 0.4116 \cdot 1000}{V} \\
& Y=\frac{a \cdot 0.1374 \cdot 1000}{V}
\end{aligned}
$$

Here: $\mathrm{X}$ is sulfate ion content, $\mathrm{mg} / \mathrm{l}$; $\mathrm{Y}$ is sulfur ion content, $\mathrm{mg} / \mathrm{1}$; A is sediment weight, $\mathrm{mg}$; $\mathrm{V}$ is sample volume of water, $\mathrm{ml}$; Coefficient of 0.4116 -boron sulfate relative to sulfate ion; Coefficient of 0.1374-boron sulfate relative to sulfur ion.

After mechanical treatment, the wastewater is collected in special aerotanks. The active "sludge" is mixed with water, and the air is sent to the microorganisms from the special bottom pipes. Under the influence of oxygen and active precipitation, the microorganisms are oxidized to form sediment. Complete completion of this process is achieved by maintaining oxygen supply, light, and temperature in a normal state. If the water temperature is low, the activity of oxidizing microorganisms decreases, and oxidation lasts longer. If the water temperature is high, the activity of harmful microorganisms will increase rapidly and will not be subject to oxidation. For several days, the oxidized water is chlorinated in separate barrels and discarded. $60 \%$ is sent for recycling.

The method of determining the total amount of chlorine is based on reducing hypochlorite, chlorite, and chlorate ions in an acidic environment from an iron salt to a chloride ion. Chloride ions are then determined by titration with ammonium thiocyanate with the addition of silver nitrate and calculated by the following formula: 


$$
X=Y-0.689 Z-0.425 q-0.526 S
$$

Here: $\mathrm{Y}$ is total amount of chlorine, $\mathrm{mg} / \mathrm{l} ; \mathrm{Z}$ is amount of hypochlorite ion, $\mathrm{mg} / \mathrm{l}$; $\mathrm{q}$ is the amount of chlorate ion, $\mathrm{mg} / \mathrm{l}$.

The total amount of nitrogen in the effluent was determined by the Keldali method. This method is based on the burning of organic matter in water with sulfuric acid as well as calcium sulfate and copper salts, in which ammonium sulphate is formed, and the ammonia formed by its leaching is detected in the Keldali apparatus. When determined by this method, the nitrogen content of the effluent is placed in a

Keldali flask with a nitrogen content of about 2-6 mg, and $10 \mathrm{ml}$ of sulfuric acid, $5 \mathrm{~g}$ of potassium sulfate, $1 \mathrm{ml}$ of copper sulfate are added and boiled. The organic matter in the water is boiled until completely dissolved, then cooled, a little water and phenolphthalein and $50 \mathrm{ml}$ of alkali $(33 \%, \mathrm{NaOH})$ are added, and $50 \mathrm{ml}$ of $0.5 \mathrm{~N}, \mathrm{H} \mathrm{SO}$ is added to the receiver in the Keldali apparatus. After complete, distillation (10ib) of ammonia, titrate 50 $\mathrm{ml}$ of $\mathrm{H} \mathrm{SO} \mathrm{SO} 0.5 \mathrm{~N}, \mathrm{NaOH}$ solution from the receiver. The total nitrogen content is then determined by substituting the following formula.

$$
\frac{(a-v) \mathrm{K} \cdot 0.28 \cdot 1000}{V}
$$

Here: a, v is $0.1 \mathrm{~N} \mathrm{N2SO} 4$ sulfate; The amount of $\mathrm{K}$ is acid titrated; 0.28 constant coefficient; $\mathrm{V}$ is waste water volume, 50 or $100 \mathrm{ml}$.

Biochemical need for oxygen (BPK). This indicator is determined in wastewater mainly by 2 different methods. "Determination of the difference between the dilution of water" and "IPC". Our study determined the BPK index based on the amount of dissolved oxygen before and after wastewater treatment; the determination of dissolved oxygen is carried out by the Vinkler iodimetric method. According to this method, the oxygen in the water is determined in water not less than $0.2-0.3 \mathrm{mg} / 1$. If oxygen was low for this concentration, it was determined by the photometric method based on the reaction of dissolved oxygen with certain dyes. When determined by the Winkler method, a precipitate of manganese hydroxide is formed in the water being analyzed, which is oxidized by dissolved oxygen in the water to form manganese hydroxide. This precipitate is soluble in the presence of sulfuric acid and potassium iodine. The released iodine is titrated with sodium thiosulfate solution until it turns white-yellow. Then the starch solution is added, and the titration is continued until the blue color disappears. In this method, the effluent is sampled before filtration, and the floating substances are separated after a certain time. Dissolved oxygen, in $\mathrm{mg} / \mathrm{l}$, is found by the following formula:

$$
\frac{a K N \cdot 8 \cdot 1000}{V_{1}-V_{2}}=\frac{a K N \cdot 8000}{V_{1}-V_{2}}
$$

where: $\mathrm{a}$ is volume of titration of thiosulfate solution, $\mathrm{ml}$; $\mathrm{K}$ is coefficient (according to the exact normality of thiosulfate); $\mathrm{N}$ is normality of thiosulfate solution; $\mathrm{V}$ is the volume of the oxygen bottle; $\mathrm{V}$ is total volume of reagent (in oxygen bottle) $\mathrm{ml}$; $\mathrm{S}$ is oxygen equivalent.

Determination of the mass concentration of total iron with thiocyanate is based on the interaction of iron oxide and thiocyanate in a strongly acidic medium with the formation of 
a red-colored complex compound of rhodane iron. The color intensity is proportional to the iron concentration. The sensitivity of the method is $0.05 \mathrm{mg} / 1 \mathrm{Fe}$.

The colorimetric method with phenol disulfonic acid is based on the reaction between nitrates and phenol disulfonic acid with the formation of nitro derivatives of phenol, which form yellow-colored compounds with alkalis. The sensitivity of the method is $0.1 \mathrm{mg} / 1 \mathrm{of}$ nitrate nitrogen.

The method is based on the hydrolysis of polyphosphates in an acidic medium, in which they transform into dissolved orthophosphates, which are determined by the colorimetric method in the form of a phosphoromolybdenum complex, colored blue. In a separate sample, orthophosphates that were originally in water are determined, the content of which is subtracted from the result obtained in the determination of polyphosphates. The sensitivity of the method is $0.01 \mathrm{mg} / 1$.

Chromium and copper determination by atomic absorption method is described below.

To determine the degree of wastewater treatment of selected wastewater-resistant plant species, we observed the daily growth and morphological status of aquatic plants in different concentrations $(100,50,25 \%)$ in a 251 spherical aquarium under laboratory conditions and as a control option in Tamiya mineral nutrient medium.

\section{Results and Discussion}

The experimental results of Binokor aeration station effluent show that the condition, growth, and productivity of the 5 species of aquatic plants tested varied when grown in the effluent, including pistachio and eucalyptus. It is observed that the yield of pistachios reaches $380 \mathrm{~g}$ (Wet biomass) per $1 \mathrm{~m} 2$. The yield of eucalyptus plants reached $330 \mathrm{~g}$, and their leaves turned yellow at the end of the experiment.

The yield of the remaining plants was 35-68 g. There was little change in the morphological condition of pistachio and eucalyptus plants for 5 days; in the remaining 3 species of aquatic plants, especially in the body of the tungsten aquatic plant, changes began to occur during growth, and on day 5, biomass growth slowed and productivity began to decline. In the Azolla plant, too, this condition began to occur after 3 days. Other researchers have shown that pistachios and eucalyptus plants grow well in other types of wastewater [3]. Based on the results of the experiments, we continued experiments to determine the growth, development, and productivity of these two types of aquatic plants pistachio and eucalyptus plants in the laboratory, as well as the level of wastewater treatment. To determine the effectiveness of biological treatment in wastewater production conditions, we must first study the growth and development of aquatic plants in wastewater under laboratory conditions and physicochemical analysis of wastewater. These results make it possible to determine the degree of purification of aquatic plants and to test them under production conditions. The results show that the pistachio plant did not grow well in 25 and 50\% nutrient media than 100\% nutrient medium, but we observed that it developed well in $100 \%$ nutrient medium and had high yields. The eucalyptus plant did not grow well in $25,50 \%$ nutrient medium but grew satisfactorily in $100 \%$ wastewater, but the yield of eucalyptus was found to be slightly lower than that of pistachio. The productivity of the pistachio plant was high even in $100 \%$ wastewater, compared to the control option, and it was observed that this wastewater is water resistant. This is because these quatic plants are found in water bodies rich in organic matter in nature [4]. 
Table 1. Physicochemical composition of pistachio aquatic plant effluents before and after cultivation in different concentrations $(25 \%, 50 \%$ to $100 \%)$ ( 7 days in the laboratory)

\begin{tabular}{|c|c|c|c|c|c|c|}
\hline $\begin{array}{c}\text { chemical } \\
\text { indicators }\end{array}$ & experiences & $\begin{array}{c}\text { After } \\
\text { experiences } \\
25 \%\end{array}$ & $\begin{array}{c}\text { Before } \\
\text { experience }\end{array}$ & $\begin{array}{c}\text { After } \\
\text { experiences } \\
50 \%\end{array}$ & $\begin{array}{c}\text { Before } \\
\text { experience }\end{array}$ & $\begin{array}{c}\text { After } \\
\text { experiences } \\
100 \%\end{array}$ \\
\hline smell & 1.2 & 0.8 & 2.5 & 1.1 & 5.0 & 1.5 \\
\hline color & 0.85 & 0.97 & 1.7 & 1.3 & 3.5 & 1.8 \\
\hline $\mathrm{pH}$ & 2.25 & 3.32 & 4.5 & 4.5 & 9.0 & 6.1 \\
\hline $\begin{array}{c}\mathrm{KBC}_{5}, \\
\mathrm{mgO}_{2} / 1 \\
\left(\mathrm{BPK}_{5} \text { ) }\right.\end{array}$ & 14.0 & 14.67 & 28.0 & 20.2 & 56.0 & 6.6 \\
\hline $\begin{array}{c}\text { Phosphates, } \\
\mathrm{mg} / \mathrm{l}\end{array}$ & 0.76 & 1.16 & 1.53 & 1.61 & 13.1 & 4.3 \\
\hline copper, mg/l & 0.64 & 0.48 & 1.28 & 0.67 & 2.6 & 0.9 \\
\hline $\begin{array}{c}\text { Ammonia, } \\
\mathrm{mg} / 1\end{array}$ & 0.95 & 1.14 & 1.90 & 1.58 & 3.8 & 2.1 \\
\hline Iron, mg/l & 1.0 & 0.6 & 2.0 & 1.1 & 4.0 & 2.0 \\
\hline $\begin{array}{c}\text { Chlorides, } \\
\mathrm{mg} / 1\end{array}$ & 12.17 & 13.15 & 24.35 & 18.15 & 48.70 & 24.20 \\
\hline Chrome, mg/1 & 0.30 & 0.16 & 0.62 & 0.31 & 1.2 & 0.6 \\
\hline Sulfates, mg/l & 9.75 & 14.1 & 19.5 & 19.5 & 39.0 & 16.0 \\
\hline $\begin{array}{c}\text { Nitrates, } \\
\mathrm{mg} / \mathrm{l} .\end{array}$ & 2.1 & 0.63 & 4.4 & 1.25 & 3.0 & 0.9 \\
\hline Nitrites, mg/l & 0.08 & 0.81 & 0.16 & 1.13 & 1.5 & 0.3 \\
\hline
\end{tabular}

Table 2. Physicochemical composition of effluents of eucalyptus aquatic plants before and after cultivation in different concentrations (25\%,50\% to $100 \%)$ (In laboratory conditions for 7 days)

\begin{tabular}{|c|c|c|c|c|c|c|}
\hline $\begin{array}{l}\text { chemical } \\
\text { indicators }\end{array}$ & $\begin{array}{l}\text { experienc } \\
\text { es }\end{array}$ & $\begin{array}{c}\text { After } \\
\text { experienc } \\
\text { es } 25 \%\end{array}$ & $\begin{array}{c}\text { Before } \\
\text { experience }\end{array}$ & $\begin{array}{c}\text { After } \\
\text { experienc } \\
\text { es } 50 \%\end{array}$ & $\begin{array}{c}\text { Before } \\
\text { experience }\end{array}$ & $\begin{array}{c}\text { After } \\
\text { experience } \\
\text { s } 100 \%\end{array}$ \\
\hline smell & 1.2 & 1.1 & 2.5 & 1.4 & 5.0 & 1.8 \\
\hline color & 0.8 & 1.3 & 1.70 & 1.69 & 3.4 & 2.1 \\
\hline $\mathrm{pH}$ & 2.2 & 4.48 & 4.50 & 5.74 & 9.0 & 7.3 \\
\hline $\begin{array}{l}\mathrm{KBC}_{5}, \\
\mathrm{mgO}_{2} / 1 \\
\left(\mathrm{BPK}_{5}\right)\end{array}$ & 14.0 & 19.74 & 28.0 & 25.3 & 56.0 & 12.0 \\
\hline $\begin{array}{c}\text { Phosphates, } \\
\text { mg/l }\end{array}$ & 0.76 & 1.56 & 1.53 & 2.01 & 13.0 & 5.8 \\
\hline copper, mg/l & 0.64 & 0.65 & 1.28 & 0.83 & 2.5 & 1.0 \\
\hline $\begin{array}{c}\text { Ammonia, } \\
\mathrm{mg} / \mathrm{l}\end{array}$ & 0.95 & 1.54 & 1.90 & 1.98 & 3.8 & 2.5 \\
\hline Iron, $\mathrm{mg} / \mathrm{l}$ & 1.2 & 0.8 & 2.4 & 1.5 & 4.8 & 2.8 \\
\hline $\begin{array}{c}\text { Chlorides, } \\
\text { mg/l }\end{array}$ & 12.17 & 17.69 & 24.35 & 22.68 & 48.70 & 29.04 \\
\hline $\begin{array}{c}\text { Chrome, } \\
\mathrm{mg} / \mathrm{l}\end{array}$ & 0.20 & 0.12 & 0.40 & 0.25 & 0.8 & 0.15 \\
\hline $\begin{array}{l}\text { Sulfates, } \\
\text { mg/l }\end{array}$ & 9.75 & 4.2 & 19.5 & 9.0 & 39.0 & 18.0 \\
\hline $\begin{array}{c}\text { Nitrates, } \\
\text { mg/l. }\end{array}$ & 2.2 & 1.5 & 4.5 & 2.0 & 1.0 & 3.0 \\
\hline Nitrites, mg/l & 0.8 & 0.3 & 1.6 & 0.6 & 0.3 & 1.58 \\
\hline
\end{tabular}




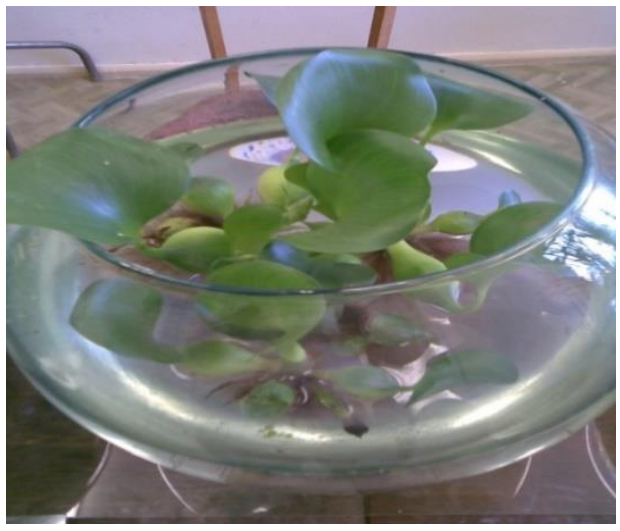

a)

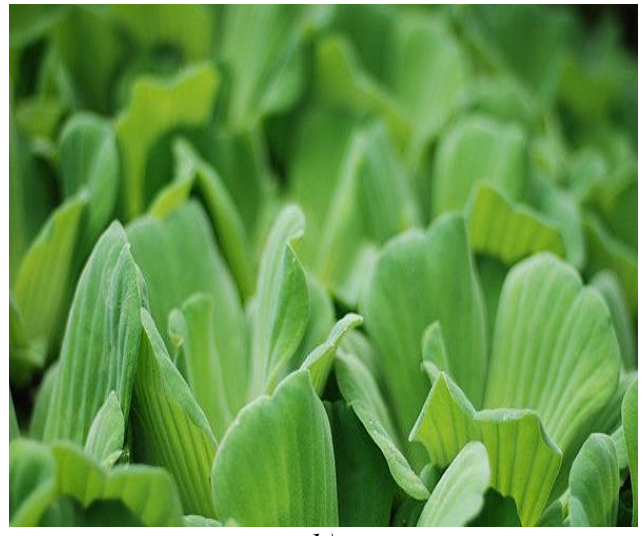

b)

Fig.1. Laboratory-grown eucalyptus: (a) and pistachio (b) general view

Thus, experiments show that wastewater does not adversely affect the growth and development of pistachio and eucalyptus plants but rather accelerates their growth. Even in the undiluted version of the effluent, the growth of the pistachio is accelerated. Because the content of organic and mineral substances in this water is higher than in other options, its growth is accelerated. It is possible to multiply pistachio and eucalyptus plants directly into it without diluting the wastewater with tap water.

We carried out a hydrochemical analysis of wastewater at different concentrations and in a standard nutrient medium after growing aquatic plants pistachios and eucalyptus and changing their growth, development, and yield to determine their purification properties before and 7 days after aquatic plant cultivation. Physicochemical analysis of water (Tables 1 and 2) shows that the odor of water decreased from 5 to 1.5 points, suspended solids in other effluents 10 times in different concentration options, dry residue up to $50 \%$, total nitrogen up to $90-100 \%$, chlorine It can be observed that the need for oxygen decreased by $45 \%$, sulfur by $60 \%$, and oxygen by $90 \%$. Similar results were obtained when pistachios and eucalyptus aquatic plants were grown in agricultural effluents (livestock, pigs) in wastewater [5].

Pistachio's wastewater oxygenation performance is slightly higher than that of the eucalyptus plant, a difference that can be seen in chemical performance and plant productivity. This is because the leaves of the pistachio plant are large and have a wide surface, which accelerates the process of photosynthesis and, as a result, ensures good growth of the plant, and its roots are dense and strong, allowing it to actively absorb nutrients. The distribution of water sources close to the sewage content may have played a major role.

To compare the experimental results at the Binokor aeration station, we continued the experiment at the Salar station in Tashkent for a chemical study. The experiments conducted at the Salar aeration station also show that out of the 5 species of aquatic plants tested, these wastewater-resistant species were found to be pistachios and eucalyptus plants. It is observed that the yield of pistachios reaches $400 \mathrm{~g}$ (Wet biomass) per $1 \mathrm{~m} 2$. The yield of eucalyptus plants reached $350 \mathrm{~g}$, and their leaves turned yellow at the end of the experiment; and from the 4th day, a similar situation was observed, and growth slowed down, and the yield of the remaining plants was only 37-70 g.

The results show that in a laboratory experiment, the pistachio plant did not grow as well as the results at Binokor station in the 25 and 50\% nutrient media of Salar compared to the $100 \%$ nutrient medium. Still, we observed that it developed well in $100 \%$ nutrient medium and had high yields. The eucalyptus plant did not grow well in 25, 50\% nutrient 
medium but grew satisfactorily in $100 \%$ wastewater, but the yield of eucalyptus was found to be slightly lower than that of pistachio.

Table 2. Physicochemical composition of pistachio aquatic plants before and after growing in different concentrations $(25 \%, 50 \%, 100 \%)$ of wastewater (In laboratory conditions for 7 days)

\begin{tabular}{|c|c|c|c|c|c|c|c|}
\hline 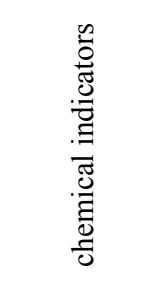 & 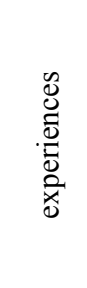 & 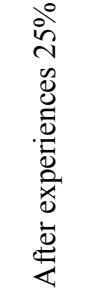 & 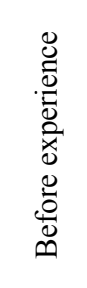 & 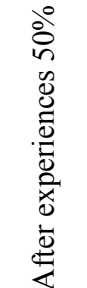 & 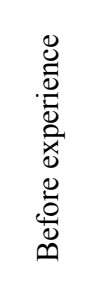 & 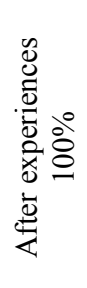 & 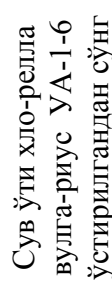 \\
\hline smell & 1.25 & 0.3 & 2.5 & 0.5 & 5.0 & 2 & 1 \\
\hline color & 1 & 0.57 & 2 & 0.95 & 4.5 & 2 & 1 \\
\hline $\mathrm{pH}$ & 3.32 & 2.25 & 4.5 & 3.1 & 9.0 & 6.6 & 7.0 \\
\hline $\begin{array}{l}\mathrm{KBC}_{5}, \\
\mathrm{mgO}_{2} / 1 \\
\left(\mathrm{BPK}_{5}\right)\end{array}$ & 64.0 & 14.5 & 128.0 & 28.3 & 256.0 & 56.1 & 23.0 \\
\hline $\begin{array}{c}\text { Phosphates, } \\
\text { mg/l }\end{array}$ & 16.0 & 4.6 & 32.0 & 6.5 & 63.1 & 12.3 & 6.5 \\
\hline $\begin{array}{c}\text { copper, } \\
\mathrm{mg} / \mathrm{l}\end{array}$ & 2.10 & 1.06 & 4.20 & 2.0 & 8.6 & 2.15 & 1.4 \\
\hline $\begin{array}{c}\text { Ammonia, } \\
\mathrm{mg} / \mathrm{l}\end{array}$ & 3.14 & 1.95 & 6.41 & 4.0 & 12.8 & 7.1 & 3.5 \\
\hline Iron, mg/l & 1.37 & 1.07 & 2.75 & 1.80 & 5.5 & 2.0 & 1.0 \\
\hline $\begin{array}{c}\text { Chlorides, } \\
\mathrm{mg} / \mathrm{l}\end{array}$ & 12.17 & 10.15 & 24.35 & 18.15 & 48.7 & 34.2 & 24.0 \\
\hline $\begin{array}{c}\text { Chrome, } \\
\mathrm{mg} / \mathrm{l}\end{array}$ & 0.45 & 0.02 & 0.92 & 0.03 & 1.8 & 0.9 & 0.4 \\
\hline $\begin{array}{c}\text { Sulfates, } \\
\mathrm{mg} / \mathrm{l}\end{array}$ & 32.0 & 10.75 & 64.2 & 24.2 & 128.0 & 38.0 & 24.0 \\
\hline $\begin{array}{c}\text { Nitrates, } \\
\text { mg/l. }\end{array}$ & 1.63 & 0.21 & 2.25 & 0.44 & 16.5 & 3.6 & 0.5 \\
\hline $\begin{array}{c}\text { Nitrites, } \\
\mathrm{mg} / \mathrm{l}\end{array}$ & 0.81 & 0.08 & 1.13 & 0.16 & 3.9 & 1.6 & 0.00 \\
\hline
\end{tabular}

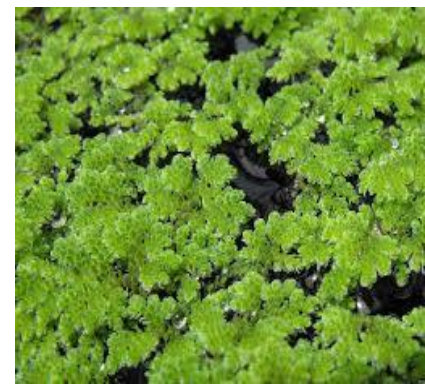

a)

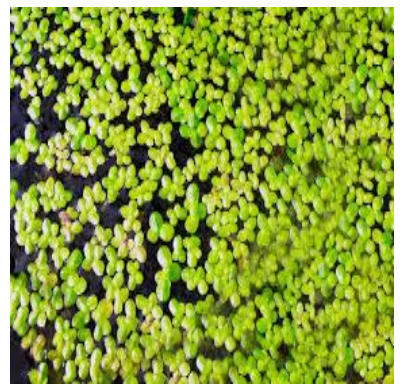

b)

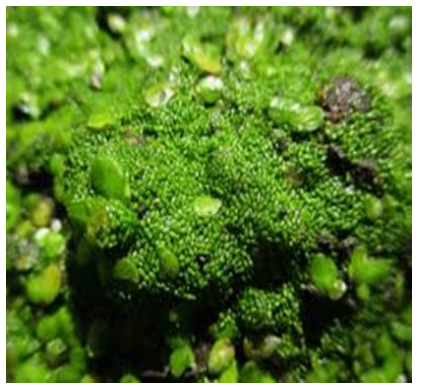

v)

Fig 3. General view of laboratory-grown azole (a), ryaska (b), tungsten (v). 
Physicochemical analysis shows that the color (Table 3) decreased from 4.5 to 2 points, the odor of water from 5 to 2 points, total nitrogen to $90-100 \%$, chlorine to $30 \%$, sulfate to $60 \%$, oxygen demand to $80 \%$. It can be observed to decrease.

It was observed that the number of pollutants in the wastewater of the Salar aeration station was significantly reduced after the cultivation of aquatic plants. The clearance rate was found to be $75-80 \%$. This is because Salar station is $70 \%$ of the amount of wastewater generated in the settlement in Tashkent, which is characterized by high levels of pollutants in the wastewater generated at another station in the city. Therefore, we also experimented with using algae to further increase the efficiency of this wastewater treatment.

Chemical analysis showed that before the growth of algae, its indicators could be seen that sulfate, nitrogen, phosphorus, and other substances significantly decreased after 5 days after the growth of algae. This is especially true in the variant grown in $50 \%$ wastewater. At the same time, the nutrients nitrogen and phosphorus are not present in the wastewater at all. By this time, it can be observed that other substances, copper, iron, chromium, have decreased significantly. The odor of the water decreased from 5 to 1 , and the $\mathrm{pH}$ decreased to 7.0. This means that by growing algae in wastewater in the second stage, it is possible to further improve their hydrochemical composition and quality.

More recently, researchers have been conducting scientific work on the biological treatment of wastewater using several similar plants. Experiments have shown that as a result of joint cultivation of wastewater from the poultry factory of Qibray district of Tashkent region aquatic plants pistachio telerizovide and small ryaska, various compounds in the wastewater are absorbed by nitrogen, phosphorus, sulfate, iron, and other substances by $70-80 \%$ and nitrogen by $100 \%$, the oxygen demand decreased to $4.5 \%$, and the level of wastewater treatment in the poultry factory in this technological process reached $95 \%$. In addition, after growing a pistachio plant, growing ryaska in the pond will speed up the wastewater treatment process and prevent the spread of sewage odors.

\section{Conclusions}

1. To study the technology of biological treatment of wastewater generated in the settlements of Tashkent, out of 5 species of aquatic

2. ic plants tested, 2 pistachio and eucalyptus species, 2 strains of algae - Chlorella vulgaris UA-1-6 strain was found to be water resistant.

3. The results of growing pistachios and eucalyptus plants in different concentrations in the wastewater of Binokor aeration station showed that the plants grew well in the $100 \%$ wastewater variant, had high yields, and significantly assimilated pollutants in the wastewater (nitrogen-72\%, phosphorus $70 \%$, sulfate- $60 \%$, iron $50 \%$, chromium $50 \%$, copper $70 \%$ ) and purification levels were $90-92 \%$. The pistachio plant was characterized by better growth in effluents, higher yields and higher absorption of harmful substances than eucalyptus. This may be because the root of the pistachio is well developed and vigorous, and the thickness and width of the fit are resistant to sewage.

4. Based on the results of experiments at the Binokor aeration station, we tested the pistachio plant at different concentrations in the sewage system at Salar station because the pistachio plant is resistant to domestic wastewater. Relatively good growth, productivity, purification levels were also found to be high. However, pistachio plant treatment was observed to be lower than the aeration sewage treatment rate in Binokor. This is because the amount of pollutants in the wastewater at the Salar aeration station is higher than in the wastewater at the Binokor aeration. For example, the amount of nitrogen in the wastewater of the Salar aeration station is $-20.4 \mathrm{mg} / 1$, in the Binokor aeration station - $4.5 \mathrm{mg} / 1$, phosphorus - $63.0 \mathrm{mg} / 1-13.1 \mathrm{mg} / 1$, sulfate - $145 \mathrm{mg} / 1-39,0 \mathrm{mg} / 1$, respectively. Therefore, it can be shown that the level of wastewater treatment is $82-86 \%$. To further 
increase the efficiency of wastewater treatment at the Salar aeration station after the aquatic plant was removed from the pistachio, it was proved that the treatment of wastewater in the 2nd biological pool reached 90-92\% (KBBT5-56-23.0 O2 / 1, nitrate 3,). 6-0.5 mg / 1, nitrate 1.6-0.00 mg / 1, phosphorus12.3-6.3 mg / 1, sulfate 58.0-24.0 mg/1).

5. So, the technology of biological treatment of wastewater at Binokor aeration station in Tashkent is one-stage; it is enough to use pistachio water plant. We consider it expedient to grow chlorella.

\section{References}

1. Matomoros Victor et al. Elimination of hazardous pollutants in wastewater by algae J. Hazardous Mater. 301 pp. 197-205 (2016)

2. Teminov M.S., Markin I. Santaev et al. Innovations in cooking technology, biotechnology and chemistry. International scientific-practical conference Saratov. pp. 207-209. (2017)

3. Ren H- Y, Liu B- F, Ma C, Zhao L, Ren N- Q. Novaya bogataya lipidami mikrovodorosl Scenedesmus sp. shtamm R-16, vydelenniy s pomoshchyu okrashivaniya Nilskim krasnym: vliyanie istochnikov ugroroda i nitrogen i nachalnogo $\mathrm{pH}$ na biomassu i produktsiyu lipidov. Biotechnology for biotopliva. 6 : 143 10.1186, (2013)

4. Ren H- Y, Liu B- F, Ma C, Zhao L, Ren N- Q. Novaya bogataya lipidami mikrovodorosl Scenedesmus sp. shtamm R-16, vydelennyy s pomoshch'yu okrashivaniya Nilskim krasnym: vliyaniye istochnikov ugroroda i nitrogen i nachalnogo $\mathrm{pH}$ na biomassu i produktsiyu lipidov. Biotechnology for biotopliva. 6 (143 10.1186). (2013)

5. Kazmiruk V.D., Kazmiruk T.N. Water purification methods of phytotechnology. Vodoochistki 5-6, pp. 66-70. (2015)

6. Khabibrahmonova A.I., Yugina N.A. Khabibrahmonov V.Z., Shulaev M.V. Biologicheskaya ochistka stochnyx vod ot ionov metodi Kazan, pp. 250-252 Peshchevye tehnologii i biotexnologii. (2016)

7. Balshakov N.Yu. Deep biological treatment of stopper water from phosphorus. Journal of Ecology 10. pp. 14-19. (2013)

8. Sbornik statey nauchno-prakticheskiy konferentsii. Aktualnoy voprosy yadernokhimicheskikh teknologii i ekologicheskoy bezopastnosti. Sevastopol pp. 145-148. (2016)

9. Biologicheskaya ochistka proizvodstvennykh stochnykh vod. Ekologiya i okhrana truda.7-8. pp. 38-41. (2013)

10. Petrovič Aleksandra, Simonič Marjana. Influence of Chlorella sorokiniana on biological denitrification of drinking water. Effect of Chlorella sorokiniana on the biological denitrification of drinking water. Environ. Sci. and Pollut. Res. 22(7). pp. 5171-5183. (2015).

11. Pope MA, Spence E., Saralvo V., Gacesa R., Heidelberger S., Weston AJ, Dunlap WC, Shick JM, Long PF. The participation of o-methyltransferase in the pentose phosphate and shikimate pathways is essential for the biosynthesis of microsporin-like amino acids in Anabaena variabilis ATCC 29413. Chembiochem 16(2). pp. 32-327. (2015).

12. Nielsen Soren Laurentius, Nielsen Hanne Dalsgaard, Pedersen Morten Foldager. Juvenile stages of the life cycle of the brown alga Fucus serratus are more sensitive to combined stress, high copper concentration and temperature than adults. Mar. Biol. 161(8). pp. 1895-1904. (2014) 
13. Ye Y., Zhang L., Yang R., Luo Q., Chen H., Yan X., Tang H., J. Agr. and Food Chem. Metabolic phenotypes associated with resistance to high temperatures in the Porphyra haitanensis lines. 61(35). pp. 8356-8363. (2013).

14. Dvoretsky D.S., Peshkova E.V., Temnov M.S. Creation of conditions for the accumulation of triglycerides in the cells of the microalgae Chlorella vulgaris IGF. Innovative technologies of healthy food: Proceedings of the International Scientific and Practical Conference dedicated to the 160th anniversary of I.V. Michurin, pp. 1518. (2015).

15. Xu X., Yin L., Gao J., Gao L., Song F. Antifungal bromophenols from sea red alga Symphyocladia latiuscula. Chem. and Biodivers. 11(5). pp. 807-811. (2014)

16. Bouchard Josée Nina, García-Gómez Candela, Rosario Lorenzo M., Segovia María. Different effects of UV light on the stress response of dinoflagellates Gymnodynium sp. and the green alga Dunaliella tertiolecta: mortality and survival. Mar. Biol. 160(10). pp. 2547-2560. (2013).

17. Sedoud Arezki, López-Igual Rocío, Rehman Ateeq ur, Wilson Adjélé, Perreau François, Boulay Clémence, Vass Imre, Krieger-Liszkay Anja, Kirilovsky Diana. The photoactive protein of the orange carotenoid of cyanobacteria is an exceptional extinguisher of singlet oxygen. Plant Cell. 26(4). pp. 1781-1791. (2014).

18. Menshova R.V., Ermakova S.P., Um B.Kh., Zvyagintseva T.N. Composition and structural characteristics of polysaccharides of brown alga Eisenia bicyclis. Biol. seas. 39(3). pp. 213-218. (2013)

19. Gerasimenko N.I., Busarova N.G., Logvinov S.V. Seasonal changes in the content of lipids and photosynthetic pigments in brown alga Saccharina cichorioides. Physiol. rast. 61(6). p. 886. (2014).

20. Li Jing, Han Danxiang, Wang Dongmei, Ning Kang, Jia Jing, Wei Li, Jing Xiaoyan, Huang Shi, Chen Jie, Li Yantao, Hu Qiang, Xu Jian. Choreography of Nannochloropsis transcriptome and lipid, revealing the mechanisms of oil synthesis in microalgae. Plant Cell. 26(4). pp. 1645-1665. (2014).

21. Herlory Olivier, Bonzom Jean-Marc, Gilbin Rodolphe. Evaluation of the sensitivity of the green alga Chlamydomonas reinhardtii to uranium using PAM-fluorometry. Aquat. Toxicol. 2. 